\title{
Clusters and Knowledge: Local buzz, Global Pipelines and the Process of Knowledge Creation
}

\author{
Harald Bathelt, Anders Malmberg \& Peter Maskell
}

\author{
Version Post-print/accepted manuscript \\ Citation Bathelt, H., Malmberg, A., \& Maskell, P. (2004). Clusters and \\ (published version) knowledge: Local buzz, global pipelines and the process of knowledge \\ creation. Progress in Human Geography, 28(1), 31-56. \\ Copyright / License \\ Publisher's Statement The version of record [Bathelt, H., Malmberg, A., \& Maskell, P. (2004). \\ Clusters and knowledge: Local buzz, global pipelines and the process of \\ knowledge creation. Progress in Human Geography, 28(1), 31-56.] is \\ available online at: \\ http://phg.sagepub.com/content/28/1/31 \\ [doi: 10.1191/0309132504ph469oa]
}

How to cite TSpace items

Always cite the published version, so the author(s) will receive recognition through services that track citation counts, e.g. Scopus. If you need to cite the page number of the TSpace version (original manuscript or accepted manuscript) because you cannot access the published version, then cite the TSpace version in addition to the published version using the permanent URI (handle) found on the record page. 
Accepted for publication in Progress in Human Geography

\title{
Clusters and knowledge: Local buzz, global pipelines and the process of knowledge creation
}

\author{
Harald Bathelt, Anders Malmberg \& Peter Maskell
}

\author{
Harald Bathelt, Professor, Ph.D., \\ Faculty of Geography, Philipps-University of Marburg, \\ Deutschhausstraße 10, D-35032 Marburg, Germany, \\ Phone +49 642128 24211, Fax + 4964212828950 , \\ E-mail: bathelt@staff.uni-marburg.de
}

\author{
Anders Malmberg, Professor, Ph.D., \\ Department of Social and Economic Geography, \\ and Centre for Research on Innovation and Industrial Dynamics (CIND), \\ Uppsala University, \\ P.O. Box 513, S-751 20 Uppsala, Sweden, \\ Phone +461847125 34, Fax +4618471 7418, \\ E-mail: anders.malmberg@kultgeog.uu.se
}

Peter Maskell, Professor, Dr.Merc.,

Danish Research Unit for Industrial Dynamics (DRUID), Department of Industrial Economics and

Strategy (IVS), Copenhagen Business School (CBS),

Howitzvej 60, DK-2000 Frederiksberg, Denmark,

Phone: +45 3815 2881, Fax: +45 3929 2226,

E-mail: pm.ivs@cbs.dk

Keywords: knowledge creation, clusters, buzz, pipelines, absorptive capacity JEL-codes: D83, L22, R10 


\begin{abstract}
The paper is concerned with spatial clustering of economic activity and its relation to the spatiality of knowledge creation in interactive learning processes. It questions the view that tacit knowledge transfer is confined to local milieus whereas codified knowledge may roam the globe almost frictionless. The paper highlights the conditions under which both tacit and codified knowledge can be exchanged locally and globally. A distinction is made between, on the one hand, the learning processes taking place among actors embedded in a community by just being there - dubbed buzz - and, on the other, the knowledge attained by investing in building channels of communication called pipelines - to selected providers located outside the local milieu. It is argued that the co-existence of high levels of buzz and many pipelines may provide firms located in outward looking and lively clusters with a string of particular advantages not available to outsiders. Finally, some policy implications, stemming from this argument, are identified.
\end{abstract}




\section{Introduction}

The riddle we are dealing with in this paper is concerned with spatial clustering of economic activity and its relation to the spatiality of knowledge creation. A condensed version of a knowledge-based theory of spatial clustering, to which the present authors have contributed in various papers in recent years, ${ }^{1}$ goes as follows. Innovation, knowledge creation and learning are all best understood if seen as the result of interactive processes where actors possessing different types of knowledge and competencies come together and exchange information with the aim to solve some technical, organisational, commercial or intellectual - problems. Such exchange and interaction can be organised in different ways. The main argument regarding the spatial aspects of this has been that - on the one hand - the more codified the knowledge involved, the less space-sensitive should these processes tend to be. If - on the other hand - the knowledge involved is diffuse and tacit, the argument is that such interaction and exchange is dependent on spatial proximity between the actors involved. Only by being in the same local environment, and by meeting repeatedly in person, can and will such more subtle forms of information be exchanged. This has been proposed as the main mechanism that makes it beneficial for a firm to be located in a spatial cluster, surrounded by other similar and related firms.

This paper grows out of a certain dissatisfaction with the above line of reasoning (see, also, Gertler 2001a), as it does not explain why interactions and transactions between firms within a cluster are often fairly limited. The aim of the following, therefore, is to develop a crude but still somewhat more sophisticated line of argument that breaks out of the simple "tacit = local"-vs.-"codified = global" model, by highlighting the conditions under which both tacit and codified knowledge can be exchanged locally and globally. ${ }^{2}$

\footnotetext{
${ }^{1}$ Cf. Malmberg and Maskell (1997, 2002), Maskell et al. (1998), Maskell and Malmberg (1999a, 1999b), Maskell (2001), Bathelt (2001, 2002), Bathelt and Glückler (2002), Bathelt and Taylor (2002).

${ }^{2}$ We are aware that tacit and codified knowledge are certainly not independent categories of knowledge (e.g. Nonaka and Takeuchi 1995, Maskell and Malmberg 1999a). In contrast, they are interdependent, complementary and dialectically interwoven. For our argument, however, it suffices to start with a simple tacit-vs.-codified knowledge dichotomy and its problematic local-global implications in order to move on to a more developed argument tackling the complex interdependencies of internal and external cluster relations and their respective information and communication ecologies.
} 


\section{Codified and tacit knowledge, local and global}

Codified knowledge may travel the world with gradually less friction thanks to relaxed trade regimes, emerging markets for intellectual property rights and improvements in information and communication technologies. Such reductions in the friction of space have sometimes led to the assumption that knowledge, once codified, is almost instantly available to all firms at zero costs regardless of their location. ${ }^{3}$ However, in reality there are usually substantial costs associated with identifying, assessing, assimilating and applying codified knowledge already in existence and use. Attaining knowledge existing elsewhere requires decisions and investments and both contribute in making the possession valuable. ${ }^{4}$ Even in cases where codified knowledge is actually almost omnipresent it may become valuable only if fused with less transitory knowledge whether proprietary or embedded in a local environment in tacit forms (Maskell et al. 1998, Asheim 1999).

One of the main distinguishing features of spatial clusters of similar and related economic activity is that they provide opportunities for the transmission of sticky, nonarticulated, tacit forms of knowledge between firms located there. ${ }^{5}$ However, when this locally embedded knowledge is combined in novel ways with codified and accessible external knowledge new value can be created. It is the quest for superior rents that compel firms in clusters not to rely on internal or local assets only, but to pursue systematically and sometimes vigorously potentially useful knowledge pools residing elsewhere (Scott 1998, Maillat 1998).

\footnotetext{
${ }^{3}$ This is, for instance, the case in recent theories of increasing returns and endogenous growth and is spilling over into the models developed within the branch of economics which is sometimes referred to as 'new economic geography' or geographical economics (Fujita, Krugman and Venables 1999).

${ }^{4}$ If neither decisions nor investments were needed codified knowledge would indeed become a ubiquity and, as realized since Weber (1909) published his seminal work, would be without much value as no superior rents can be earned on ubiquities.

${ }^{5}$ There may be several, mutually reinforcing, reasons for the ease with which knowledge is communicated at the local level. Lawson and Lorenz (1999) emphasise, for instance, how actors in a cluster develop a common language, joint interpretative contexts and a shared knowledge basis. Grabher (2002b) demonstrates how colocation facilitates the establishment of common interpretative schemes, especially through 'hanging out' in local 'communities of practice' (Brown and Duguid 1991, Wenger 1998). Such features have, furthermore, been proposed as a general explanation for the existence of clusters as well as for their sustained economic success (Malmberg and Maskell 1997).
} 
This line of reasoning makes us suspect that the particularly successful clusters are the ones that are able to build and maintain a variety of channels for low-cost exchange of knowledge with relevant hot-spots around the globe (Bathelt 2001). ${ }^{6}$ Although it has been acknowledged by many scholars from different academic schools - ranging from the industrial districts literature (e.g. Goodman, Bamford and Saynor 1989, Pyke, Becattini and Sengenberger 1990) to studies of innovative milieus (Camagni 1991, Ratti, Bramanti and Gordon 1997) and transaction cost-based analyses (e.g. Scott 1988, 1998) - that external sources of knowledge are often important triggers to stimulate growth within a cluster, there is little systematic analysis that deals with the question of how the structure of interactive and knowledge-enhancing relations between firms differ within and across clusters. This mismatch in empirical observation and conceptualisation has stimulated debate in recent years. Humphrey and Schmitz (2002: 1018f) conclude for instance that " $[\mathrm{t}]$ he cluster literature emphasizes the importance of local-level governance. ... Links with the wider world are [in such literature] frequently acknowledged, but they are weakly theorized." (emphasis added). ${ }^{7}$ Using these and other studies as a point of departure, we would like to shed some light on the complex nature of social relations in knowledge-creation processes within and across clusters. This will done primarily through a conceptual lens.

\section{Aim and structure of the paper}

We maintain that the skills and efforts required when attending to the local environment are rather different from the ones necessary to maximise the inflow and utilisation of codified knowledge produced elsewhere, and that these differences must be managed. In this paper, our aim is thus to present an admittedly crude model that takes into account the global connections of firms in clusters while retaining the notion that in some crucial sense knowledge is created, stored and utilised locally in a decisive manner. In doing this, we do not intend to explore all possible local-global production configurations. We refer to the specific cases of clusters based on knowledge creation capabilities.

\footnotetext{
${ }^{6}$ The tendency in some contemporary writings on clusters and knowledge creation to emphasise localised learning and agglomeration factors rather than extra-local influences, that are not defined geographically, should therefore be questioned (Oinas 1999, Vatne 2001).

${ }^{7}$ Despite this conclusion, Humphrey and Schmitz (2002) primarily deal with this shortcoming from a global value chain perspective providing an analysis of the localised effects and prospects of upgrading strategies within such commodity chains.
} 
Our argument proceeds in the following way. In the next section we identify some important properties of knowledge creation within firms while emphasising reasons why many firms need access to knowledge produced elsewhere. In section three we take a closer look at inter-firm knowledge creation at the local level, within the framework of geographical agglomerations or spatial clusters of similar and related economic activities. In section four we move on to what is the pivotal argument of this paper: the need to go beyond the borders of the cluster and build pipelines to bodies of knowledge residing elsewhere. This section discusses how this may be done and the balance that firms need to negotiate when attempting to reap the benefits of both worlds: the local and the global. The final section summarises the argument of the paper and presents, by way of conclusion, a simple model and its implications.

\section{Knowledge creation within and across firms}

A main argument in the contemporary literature on learning and innovation is that these are the result of interactive processes in which different actors come together to collaborate in solving particular problems. While much of this literature focuses on network relations between firms, we believe that it is important to start out considering the learning process that takes place within the firm, before turning to the role of interfirm interaction.

\section{Knowledge creation within firms}

Learning within firms can take place in many different ways (Simon 1991) but is often closely related to the ongoing activities extending the existing internal knowledge pool (Fuchs 2001, Tracey, Clark and Lawton Smith 2002). A firm constitutes a common interpretative context based on the visions, values, and memories in the form of artefacts, routines and experience which help to ensure that what each employee learns is in some way connected to what the other employees might know or learn (Loasby 1999, Lawson and Lorenz 1999). But as knowledge is in itself an important source for further knowledge creation small initial individual differences increase over time even when sharing common experiences. As the firm matures its knowledge stock will, consequentially, grow in an uneven fashion and gradually become less coherent. The larger the firm becomes the fewer experiences are shared across all sections and 
employees and what was initially a homogeneous initial body of knowledge becomes fragmented into a complex pattern of only partly overlapping fields of expertise, with connections and objectives no longer in full accordance with each other.

There is, of course, no fixed upper limit regarding the number of distinct fields within which a firm might maintain competencies, but the costs of mastering a broad array of different competencies often appear to outweigh the benefits (Pavitt 1999). The reason for this is that each body of knowledge, which a firm possesses, is often linked to distinct technologies and associated with the performance of certain tasks, that may require a particular set of criteria for decision-making and a specific style of management. Furthermore, each field of competence usually requires some sort of dedicated vision and targeted effort, somewhat different from the demands of all other fields of the firm's knowledge base (Loasby 2000). So though the existence of divergent knowledge pools within a firm may give rise to learning advantages (Simon 1985) they are also the constant source of coordination and switching costs. ${ }^{8}$

\section{Cross-departmental knowledge creation}

The tensions of maintaining a heterogeneous knowledge base within a single firm can, of course, to some degree be kept at bay by taking refuge to the formation of a divisionalized internal structure of the firm (Chandler 1962). ${ }^{9}$ While likely to minimise the managerial 'control loss problems' (Teece 1980), the benefits are often obtained at the expense of the cross-divisional synergies that constituted the raison d'être for diversification. The ensuing difficulties in crossing departmental layers within the divisionalized company might at least partly help to explain the "... somewhat ironic fact that many managers consider internal transactions to be more difficult than external ones, even though vertical integration is pursued for presumed advantages" as Eccles (1983: 28) once pointed out. ${ }^{10}$

\footnotetext{
${ }^{8}$ The line of argument in this and the two following sections stems, of course, from Adam Smith's (1776) initial conjecture regarding the learning advantages associated with the division of labour and from von Hayek's $(1937,1945)$ suggestions about the nature of distributed knowledge and the way it may be assembled and used.

${ }^{9}$ See also Kie and Hynes (1996) for an empirically founded critique of the vertical disintegration hypothesis that underlies much contemporary writing in economic geography.
} 
Multidivisional firms do nevertheless often have substantial advantages in being able to combine expertise from a broad range of fields. When experts from different departments get together to develop a new product, the first stage will usually involve the presentation of different types of knowledge relevant for this new development. This requires that various sources of tacit knowledge are articulated and explicated to allow for its evaluation and discussion by those who are not familiar with it. The next stage involves the re-combination and connection of the various explicit knowledge pools in such a way as to develop a new product conception. This can be done in rounds of structured discussion and brain storming. Once this stage has resulted in a new product conception, this knowledge has to be internalised (embodied) into the technical systems and employees' routines to build and test a prototype. Finally, this tacit knowledge is constantly being transformed and perfected through processes of learning and socialising. Through this, production can be organised with lower costs over time (Nonaka and Takeuchi 1995, Lawson and Lorenz 1999).

It is obvious that the various stages in this knowledge-transformation process require different internal organisational structures to be executed efficiently (Nonaka, Toyama and Nagata 2000). The process of articulating various types of tacit knowledge and recombining them into a new product conception might, for instance, be best organised in a project team of experts who get together for a limited time period to achieve a clearly defined goal (Maskell and Lorenzen 2003). ${ }^{11}$

\section{Knowledge creation across firms}

The insistence that radical knowledge creation is usually an interactive process across several firms emanates from recent innovation studies, but has been around for quite some time (Rosenberg 1982, Freeman 1982, 1991, Kline and Rosenberg 1986, Lundvall 1988, Håkansson 1989, Hagedoorn and Schakenraad 1992, OECD 1992, Gertler 1993, 1995, DeBresson et al. 1997). The 'National Innovation Systems' approach uses this insight as its most basic building block (Lundvall and Maskell 2000), but the idea that

\footnotetext{
10 This general tendency does not, of course, imply the total absence of real-life situations where horizontallyand vertically-integrated firms have outlived more specialized firms (Staber 1997).

${ }^{11}$ Nonaka, Toyama and Nagata (2000) use the Japanese concept of 'ba' to refer to the organisational contexts within which individuals interact at a specific time and place over a certain time period when exchanging an creating knowledge. For its application in a European context, see Kostiainen (2002).
} 
the division of labour is a device for developing knowledge is, of course, much older and constitutes the foundation for Adam Smith's theory of economic growth, outlined in the first chapters of the Wealth of Nations (Smith 1776). Here, Smith (1776) identified how scientific as well as non-scientific knowledge becomes more specialised as it develops, leading to the apprehension of detailed anomalies that would else easily be overlooked and thus contributing to an acceleration of the growth of knowledge. Even when specialising in performing some particularly trivial tasks individuals find solutions and notice peculiarities otherwise overlooked. By creating an appropriate differentiation, a group of firms can therefore develop knowledge far beyond the reach of any single member of that group. With the growth of knowledge, new economic activities become possible; the economy progresses; and the resulting extension of the market makes this process self-reinforcing (Young 1928). The continual process of knowledge creation resulting from the division of labour contributes to the variation needed for future beneficial reassemble of knowledge. The division of labour among firms thus impacts directly on the (possible) level of learning in the economy.

There is, however, a flip side to the advantages obtained by the steady increase in the division of labour. The resulting dispersion of knowledge between firms also increases the cognitive distance that firms have to overcome when utilising different bodies of knowledge in their ongoing activities, particularly when they engage in inter-firm product development projects (Storper and Venables 2002). The knowledge heterogeneity required for successful inter-firm knowledge creation is therefore subject to both thresholds and ceilings. The knowledge-bases of firms must be sufficiently different to make interaction worthwhile, hence allowing learning processes to take place. At the same time, if the cognitive distance becomes too great or the knowledgebases too dissimilar then inter-firm learning will cease (Nooteboom 2000). Firms build external relationships when struggling to obtain a profitable balance between the two. We suspect that clustering of related economic activities may be a particularly useful strategy for striking a profitable balance. This will be dealt with in the next section.

\section{Knowledge creation within clusters: the nature of local buzz}

In recent work, Porter (2000: 254) defines a cluster as "a geographically proximate group of inter-connected companies and associated institutions in a particular field, 
linked by commonalities and complementarities", while also stating that the geographic scope of a cluster can "range from a single city or state to a country or even a group of neighbouring countries." "12 This broad characterisation says, however, very little about the advantages firms have when locating within a cluster. ${ }^{13}$ To answer this question one may distinguish between the horizontal and vertical dimensions of a cluster and identify the advantages of local or regional as opposed to extra-local or inter-regional interaction between firms (Maskell 2001a, 2001b, Malmberg and Maskell 2002, Bathelt 2002).

\section{Cluster dimensions}

The horizontal dimension of a cluster consists of those firms that produce similar goods and compete with one another. This dimension can play a decisive role in the early stage of cluster formation and specialisation. Porter $(1990,1998)$ has demonstrated that strong competition and rivalry between firms is an important incentive for innovation and product differentiation. These firms do not necessarily have close contacts to one another or intensive input-output relations involving substantial physical transactions. Rather, the respective firms benefit from their co-location through which they are well informed about the characteristics of their competitors' products and about the quality and cost of the production factors that they use. Advantages of proximity arise from continuous monitoring and comparing. Due to their co-presence, the production conditions are basically the same for all regional firms. This enables the firms to effectively compare their performance with that of their competitors. Overall, this creates rivalry and serves as an incentive for product differentiation and variation.

The vertical cluster dimension consists of those firms which are complementary and are inter-linked through a network of supplier, service and customer relations. Already Marshall (1920: 225) described the process of how variety at the horizontal level stimulates growth in the vertical dimension: "[...] if one man starts a new idea, it is taken up by others and combined with suggestions of their own; and thus it becomes the source of further new ideas. And presently subsidiary trades grow up in the neighbourhood, supplying it with implements and materials, organizing its traffic, and in many ways conducing to the economy of its material." The idea behind this is that,

\footnotetext{
${ }^{12}$ For a critique see Martin and Sunley (2001).

${ }^{13}$ For a challenging different interpretation see Klepper (2002).
} 
once a specialised industry cluster has been established, the firms of this cluster develop a demand for specialised services and supplies. ${ }^{14}$ This creates an incentive for suppliers to be near these firms because they form important markets. In locating close to these markets, the suppliers can gain economies of scale and distribute large parts of their production at low costs (i.e. transaction and transportation costs). As a consequence, one would expect the development of dense networks of transaction and material linkages within a cluster. ${ }^{15}$

However, it has been well-known for a long time that clusters and agglomerations are seldom characterised by strong internal input-output linkages. ${ }^{16}$ Karaska's (1969) classical study of input-output linkages in the Philadelphia manufacturing sector revealed that only a relatively small percentage of material linkages took place within the region. This modest importance of regional input-output linkages has been confirmed in many studies of older industrial regions (e.g. Gilmour 1974, Erikson 1975, Pred 1976), as well as high-technology production spaces (e.g. Schickhoff 1983, Chapman and Walker 1987). ${ }^{17}$

\section{Localised capabilities}

Recent contributions by Storper (1995, 1997), Maskell and Malmberg (1999a, 1999b), Lawson (1999) and others have pointed out that the existence of economies of scale and other kinds of traded interdependencies is simply not enough to understand the

\footnotetext{
${ }^{14}$ Marshall's initial reflections have been followed by contributions from a vast range of scholars - from Weber (1909) to Krugman $(1991,2000)$ - while adding only marginally to the basic argument.

15 The cluster dimensions are not independent from one another. They may reinforce one another but there can be also trade-offs between openness and embeddedness, co-operation and competition, vertical and horizontal diversification, and so on. If, for instance, networks are characterised by ossification, new ventures in the cluster will have difficulties obtaining access to internal resources (e.g. Grabher 1993), as they might be blocked by the existing actors. In this case, they would have no other chance but to develop external ties. Only through the continued growth of a cluster can these trade-offs be kept at bay without conflict (Bathelt and Taylor 2002, Malmberg and Maskell 2002).

${ }^{16}$ Of course, case studies do exist which provide evidence of important intra-regional transactions between a cluster's actors, such as those in some Italian industrial districts (e.g. Goodman, Bamford and Saynor 1989, Pyke, Becattini and Sengenberger 1990, Amin and Thrift 1992).

${ }^{17}$ Even in the San Francisco Bay area, which encompasses Silicon Valley, local transactions between high technology firms are much lower than would be expected. In a survey of high-technology small firms, Oakey, Rothwell and Cooper (1988) found that more than $45 \%$ and $70 \%$ of their respondents acquired their inputs and dispatched their sales primarily outside the region, respectively. If it is not the cost advantage of intraregional input-output linkages, what are then the incentives for firms to locate within a cluster and remain there?
} 
processes behind spatial clustering. In emphasising 'localised capabilities' and 'untraded interdependencies', it has been shown that socio-institutional settings, interfirm communication and interactive processes of localised learning play decisive roles in processes of innovation and growth (Maskell et al. 1998, Gordon and McCann 2000, Bathelt and Glückler 2002).

Overall, the shared knowledge basis enables cluster firms to continuously combine and re-combine similar and non-similar resources to produce new knowledge and innovations. This stimulates economic specialisation within the cluster and results in the development of localised capabilities (Maskell and Malmberg 1999a, 1999b) which are available to cluster firms.

A location within an industrial cluster brings further advantages that are not available to firms situated elsewhere. Again, Marshall (1927) expressed this in his famous notion of 'industrial atmosphere', as being something that is 'in the air', limited to the people within a particular region or place. Through observations in the cutlery industry of Sheffield and Solingen, Marshall (1927: 284) concluded that such places "have acquired industrial 'atmospheres' of their own; which yield gratis to the manufacturers of cutlery great advantages, that are not easily to be had elsewhere: and an atmosphere cannot be moved."

Atmosphere, broadcasting, noise, buzz: the exclusive quality of the cluster

Marshall's 'industrial atmosphere' concerned the industry-specific cluster advantages usually referred to as 'localisation economies', but his general idea has lately been taken up and extended to become a more general statement about the advantages that may accrue from the geographical propinquity of industries and services in general ('urbanisation economies'; cf. Hoover 1970). Storper and Venables (2002) have, for instance, recently identified what they see as a particularly important sub-set of urbanisation economies, which they label 'buzz'. In a similar way, Owen-Smith and Powell (2002) use the notion of 'local broadcasting' and Grabher (2002a) the term 'noise' to denote something similar: the idea that a certain milieu can be vibrant in the sense that there are lots of piquant and useful things going on simultaneously and therefore lots of inspiration and information to receive for the perceptive local actors (see also Crevoisier and Maillat 1991, Maillat 1998). Buzz refers to the information and 
communication ecology created by face-to-face contacts, co-presence and co-location of people and firms within the same industry and place or region. This buzz consists of specific information and continuous updates of this information, intended and unanticipated learning processes in organised and accidental meetings, the application of the same interpretative schemes and mutual understanding of new knowledge and technologies, as well as shared cultural traditions and habits within a particular technology field, which stimulate the establishment of conventions and other institutional arrangements. Actors continuously contribute to and benefit from the diffusion of information, gossip and news by just 'being there' (Gertler 1995).

Participating in the buzz does not require particular investments. This sort of information and communication is more or less automatically received by those who are located within the region and who participate in the cluster's various social and economic spheres. In this context, "actors are not deliberately 'scanning' their environment in search of a specific piece of information but rather are surrounded by a concoction of rumours, impressions, recommendations, trade folklore and strategic information ..." (Grabher 2002a: 209). It is almost unavoidable to receive information, rumours and news about other cluster firms and their actions. This does not imply however that an agglomeration of firms always creates the same sort of buzz. Intensive local buzz is neither a direct consequence of co-location, nor is all sort of buzz equally relevant to the firms of a cluster. In fact, the diffusion of buzz within a cluster can go smoothly but it can also be somewhat blocked depending on the structure of social relations between the local actors and firms and the history of interactions between them (Bathelt and Glückler 2002). Especially in cases where distrust and malfeasance exist, it is unlikely to have high-quality local buzz. Since there are different configurations of localised production systems (e.g. Markusen 1996), we can also expect that different types of buzz develop. Of course, buzz is never just saying 'hello' to some other cluster actors. It refers to the network of communication and information linkages which develop within a cluster. This occurs in negotiations with local suppliers, in phone calls during office hours, while talking to neighbours in the garden or when having lunch with other employees and so on. The nature of buzz is spontaneous and fluid. Copresence within the same economic and social context generates manifold opportunities for personal meetings and communication. These meetings can be planned or occur spontaneously. They can be non-designed, non-targeted and more-or-less accidental. 
Hence, as pointed out by Uzzi (1997: 52), "network ties link actors in multiple ways (as business partners, friends, agents, mentors), providing a means by which resources from one relationship can be engaged for another. In investment situations, these factors increase an actor's capacity to access resources, adjust to unforeseen events, and evaluate risks." This is particularly the case in the context of a cluster which has a rich history of social interaction and offers opportunities for multiplex relationships, face-toface contacts and meetings. Over time, these structures of social relations stimulate finegrained information transfer, joint problem-solving arrangements and the development of trust and reciprocity (Granovetter 1985, Uzzi 1997).

Therefore, different modes of communication operate in a cluster's social and economic context (e.g. chatting, gossiping, brainstorming, in-depth discussions, problem analysis). Co-location and visibility generate potentials for efficient inter-personal translation of important news and information between the cluster actors and firms, as has been emphasised by actor-network theory (Latour 1986, Allen 1997). Coherence within the cluster is established by particular learning processes, path dependence, complementary resources, technological opportunities and selection environments (Murdoch 1995). This is supported by the actual movement of employees with embedded skills, which are not easily learnt, between firms (Møen 2001, Almeida and Kogut 1999, Rosenkopf and Almeida 2001).

Being located in the same place also enables firms to understand the local buzz in a meaningful and useful way. This is because co-location within a cluster stimulates the development of a particular institutional structure shared by those who participate. Firms develop similar language, technology attitudes and interpretative schemes (Lawson and Lorenz 1999). Also, as has been suggested elsewhere (Maskell et al. 1998), trust exists in local milieus as something inherited, that any 'insider' will benefit from by default. ${ }^{18}$ This process of institution building is triggered by the establishment of 'communities of practice' (Brown and Duguid 1991, Wenger 1998). These consist of agents which are bound together by through day-to-day interaction, based on the same

\footnotetext{
${ }^{18}$ Following Lorenz (1999: 305), we view trust "as the judgement one makes on the basis of one's past interactions with others that they will seek to act in ways that favour one's ideas, rather than harm them ...". Trust means that an actor within a cluster knows that he/she can in all probability rely on others in terms of production quality and capabilities. Firms would of course also be aware of others which are not reliable and who they should not to do business with.
} 
expertise, a common set of technological knowledge and similar experience with a particular set of problem-solving techniques. Such communities can develop within a firm but also span a single organisation and include other firms of a value chain (Gertler 2001b). Shared experience in the same technologies and ongoing attempts to solve the same sort of problems, based on basic understandings and similar technological paradigms support the development of mutual engagement, joint enterprise, shared repertoire and negotiation of meaning. Communities of practice thus lead to the generation of distinct routines, conventions and other institutional arrangements. Learning within these communities is due to convergence in the sense of mutual relationships, shared ways of interacting, knowledge about other agents and their competencies, shared language and attitudes and the like (Wenger 1998). This enables particular decisions to follow earlier particular decisions and specialised communication to follow earlier specialised communication. Clusters can become important catalysts for the formation of such communities. In this case, they develop into local frames to understand the meaning and significance of local buzz which in turn serves to stimulate the generation of local buzz and its rapid diffusion.

\section{Knowledge creation across clusters: the nature of pipelines}

While a large number of studies in economic geography and related social sciences have emphasised the importance of local networking (e.g. Scott 1988, Saxenian 1994, Maillat et al. 1997, Ratti, Bramanti and Gordon 1997) relatively few empirical studies have actually provided convincing empirical evidence of the superiority of local over nonlocal interaction, aside from some well-known case studies on industrial districts and creative milieus (see, also, Markusen 1996). Empirical work on regional linkage patterns has provided evidence that even in regions, such as the San Francisco Bay area and Baden-Württemberg which are often portrayed as prototypes of regional networking, internal transactions are by no means dominant over external relations (Oakey, Rothwell and Cooper 1988; Grotz and Braun 1993). Not surprisingly, an increasing number of studies have begun to question the seemingly dominant character of local learning processes (Malecki and Oinas 1999, Bathelt 2001, Gertler 2001a, Vatne 2001). Oinas (1999: 364), for instance, finds that "[t]here is relatively little research on 'actual learning processes' to give support to the claims about 'localised learning'. As learning processes are not empirically documented, the mere 
agglomeration of successful firms in an industry seems to be assumed to signify localised learning". And further, "it seems evident that the creation of new knowledge (learning) might be best viewed as a result of a 'combination' of close and distant interactions" (p. 365).

\section{The need for pipelines}

Owen-Smith and Powell (2002) use the term 'pipeline' to refer to the channel used in such distant interactions. They conclude from their study of the Boston biotechnology community that even though knowledge spillovers may be more effective within a regional network than across its borders, physical distance is not the only influence. Decisive, non-incremental knowledge flows are often generated through 'network pipelines', rather then through undirected, spontaneous 'local broadcasting'. Utilising this concept, Owen-Smith and Powell (2002) have shown in the case of the Boston biotechnology industry that access to new knowledge does not just result from local and regional interaction but is often acquired through strategic partnerships of inter-regional and international reach. Boston's biotechnology firms are thus not only embedded in regional innovation networks but also in social networks which are not defined regionally or by any other discrete spatial level. Grabher's (2002b) study of Soho's 'ad village' in London, as well as Scott's (2002) analysis of the Hollywood motion picture and entertainment cluster, also emphasise the importance of extra-local linkages to create knowledge and produce local growth.

While interaction and information exchange within the cluster - the local buzz - is characterized by being frequent, broad, relatively unstructured and largely "automatic", pipelines function in a very different way.

Once a potential partner from the outside has been found, it has to be decided how much information should be given to that partner and to which degree the activities of that firm have to be monitored or controlled. The resulting interaction is thus greatly impacted by the degree of trust that exists between the firms. Unlike in the case of local relations between cluster firms (Maskell and Malmberg 1999a), there is no shared trust in this situation from which the new partners can benefit. Instead, the establishment of global pipelines with new partners requires that new trust is being built in a conscious and systematic way. This process of building up trust takes time and involves costs 
(Harrison 1992). Lorenz (1999) has pointed out that this can be accomplished through a set of procedural rules involving a sequence of transactions and interactions wherein small risks are followed by larger ones and commitments progressively increase. ${ }^{19}$

Now, one could indeed argue that the extra-local knowledge flows (through the pipeline system) are not dependent on the local buzz. On the contrary, from case studies, such as those of the film industry in Los Angeles, advertising industry in London and hightechnology industry in Silicon Valley it could be expected that the two are mutually reinforcing. The more firms of a cluster engage in the built-up of trans-local pipelines the more information and news about markets and technologies are 'pumped' into internal networks and the more dynamic the buzz from which local actors benefit. ${ }^{20}$ Because of their potential to intensify local interaction, global pipelines support a cluster's cohesion and strengthen the internal translation processes between cluster actors (Murdoch 1995).

The GREMI approach to innovative milieus (Maillat, 1998, Camagni, 1991, Ratti et al., 1997) also joins the call for actors in a local milieu to establish systematic linkages with external information sources to maintain the flow of important information about market trends and new technologies into the milieu (Perrin 1991, Quévit 1991). Otherwise, it is claimed, a milieu runs the risk of stagnating (Maillat 1998). From a study of a larger number of industrial clusters in different parts of the world, Bresnahan et al. (2001) have, furthermore, found that the reasons behind the establishment of a new cluster are much different from those which support the growth of an existing cluster. In their comparative study of information and communication technology

\footnotetext{
${ }^{19}$ In a case study of the restructuring in the Lyon machine-building industry, Lorenz (1999) shows how trust can develop through such procedural rules between producers and suppliers as a consequence of learning.

${ }^{20}$ Of course, the particular mix of local buzz and global pipelines can vary across value chains, technologies and markets segments. Some industries (e.g. fashion products) might, for instance, require more buzz than others (e.g. steel production), while other industries would need more pipelines (e.g. biotechnology). We would argue though that a mix of both is always required to ensure continued growth and innovation. A particularly interesting combination of local buzz and global pipelines which is mutually reinforcing can be found in New York City's women's wear industry which forms a distinct cluster in the Garment District. The creativity of this cluster is based on interaction between the buyers, designers, specialised producers and services, enriched by impressions from fashion magazines, designer schools, trade shows and the like (Uzzi 1996). This location provides an advantage for firms as it generates openness and swift access to external influences just by being there. Due to its creativity and leadership in design, the women's wear industry attracts designers and other creatives from all over the world. Unlike in many other places, New York City's producers do not have leave the city to tap into new knowledge pools. These pools already exist in New York (e.g. in the Lower East Side) and are constantly being reproduced (Rantisi 2002).
} 
clusters, they found that external effects, agglomeration factors and networking synergies did not have a large impact in the early stages of development. Instead, outstanding entrepreneurial activities, their willingness to take the risk of starting up new ventures and their ability to tap into new areas outside the established technologies and markets have been decisive for the genesis of those clusters studied. The success of these entrepreneurial endeavours largely depended on the firms' ability to access major markets outside the cluster in their early stages. In addition, such clusters have been able to attract specialised skills from other localities and regions. According to the work of Bresnahan et al. (2001), the openness of cluster relations and active search for large external markets is therefore key in understanding the rise of successful clusters.

In a similar vein, Scott (1998) has emphasized that the performance of localised production systems depends on the right mix of local and non-local transactions and that strong growth can only result if external markets are linked to the production cluster. Although they point out the importance of external linkages, Maillat (1998) and Scott (1998), like many others, concentrate on the analysis of local networks and do not provide a deeper understanding of the nature of non-local linkages. Although Amin and Thrift (1992) pointed out that it is misleading to create a simple local-global dialectic as both are closely intertwined and stimulate one another - there still seems to be a missing link in the conceptualisation of the connection between internal and external cluster relations (Humphrey and Schmitz 2002).

Another group of studies emphasises the need of extra-local linkages by referring to the dangers of local networks that are too close, too exclusive and too rigid. Such social relations could pose a threat to the competitiveness of a firm or a group of firms. In an empirical study of the New York textile industry, Uzzi $(1996,1997)$ has found a phenomenon that he refers to as over-embeddedness. He demonstrates that close social relations of suppliers with their local customers are only positive to a certain extent. The stronger a large group of suppliers is embedded with the same set of customers, the more likely are firms to fail. From a different point of departure, Burt (1992) emphasises the importance of those actors which are able to make connections between otherwise remote networks. These are non-redundant linkages which bridge 'structural holes'. He refers to these network relations as 'plumbing' through which information and resources are being transmitted. Kern (1996) emphasises that attempts to 
consciously open network relations for the influx of external information, as well as maintaining a certain amount of distrust with respect to traditional solutions, is important to avoid lock-in, while Malecki (2000) draws attention to the significant difference between 'introvert' and 'extrovert' firms. Even if a firm over time achieves a sufficiently successful balance between being too much inward- or too much outwardlooking it is nevertheless only able to handle a limited number of external linkages, as Grabher (2001, 2002b), for instance, observed when studying London's advertising industry. This is because the establishment and maintenance of external linkages requires substantial time and efforts. They are not created automatically and do not continue to exist without regular communication and interaction.

Overall, communication processes in global pipelines are contingent by nature and are plagued by great uncertainty. Common institutions and procedural rules are established step-by-step, constantly being reshaped by experience (Lorenz 1999). Over time this enables fine-grained information transfer and co-operation in more complex projects. Because global pipelines encompass firms from different parts of the world which are embedded in different socio-institutional and cultural environments they operate in multiple selection environments (Owen-Smith and Powell 2002). This is particularly important in innovative industries where leading-edge knowledge constantly changes and new and better products and processes evolve. Once a pipeline has successfully been established and works effectively based on a common set of institutions it provides substantial advantages to that local actor. It enables the actor to go beyond the routines of the local cluster. A firm may choose between different technological and organisational options and select those which are robust towards changes in the institutional settings.

Thus, it can be hypothesised that both local buzz and global pipelines offer particular, albeit different, advantages for firms engaged in innovation and knowledge creation. ${ }^{21}$

\footnotetext{
${ }^{21}$ One could argue that the buzz-and-pipeline argument carried out in this paper is at odds with Granovetter's (1973) classic work on the strength of weak ties. Therein, Granovetter (1973) has illustrated that strong ties are rarely able to bridge the gap between different networks. He points out that particularly weak ties are able to bridge the gap between networks and, thus, allow one network to source new knowledge from another. We do not intend to imply that weak ties are dominant at the local level, while strong ties dominate the global. In accordance with Granovetter (1973), we suggest that weak ties at the periphery of a network are especially important for the diffusion of breakthrough innovations which would otherwise be slowed down by strong ties in the network core. Of course weak ties are very important in the local buzz which characterises the communication flows between the actors of a cluster. For the same reasons, weak ties are also extremely
} 
Local buzz is beneficial to innovation processes because it generates opportunities for a variety of spontaneous and unanticipated situations where firms interact and form interpretative communities (Nonaka, Toyama and Nagata 2000). The advantages of global pipelines are instead associated with the integration of multiple selection environments that open different potentialities and feed local interpretation and usage of knowledge hitherto residing elsewhere. Malecki (2000: 341) concludes this line of reasoning when stating that "[s]ome places are able to create, attract, and keep economic activity ... [particularly] because people in those places 'make connections' with other places ...”.

\section{The limitations to pipeline formation}

Tapping into an external pool of knowledge and establishing new relations with distant firms requires conscious efforts. In contrast to the type of communication and interaction that often occurs within the cluster, cost considerations tend to make the knowledge flows and interaction in global pipelines targeted towards a certain, often pre-defined goal. As a consequence, they are usually more focused and narrow. Unlike the local buzz, information flowing through global pipelines has an intrinsic bias towards filtering information of failures even when knowledge of what went wrong could be highly useful. ${ }^{22}$

Furthermore, knowledge flows through pipelines are not automatic and participation is not free. The processes behind the establishment and maintenance of global pipelines must be pre-designed and planned in advance, and they require specific investments. This involves a complex and costly process. One of the first decisions to be made here is the selection of external partners. This is not easy because information about the set of potential partners is usually truncated and the knowledge of these firms and their

\footnotetext{
important when making decisions about which outside technologies and markets to tap into and which external partners to select for pipeline investments. Such weak ties are, for instance, established through conventions and trade fairs where technologically sophisticated and dynamic international firms communicate over a limited time period.

${ }^{22}$ In contrast with the information flows in global pipelines, the local buzz spreads information of both the successes and failures of other actors and their projects. To go beyond the regional cluster and engage in global pipelines is, to some extent, more risky because information flows about other firms are biased towards successful endeavours at this level and tend to overlook the not-so-successful. It is especially the outstanding successes which make their way through global communication channels.
} 
actual capabilities incomplete (Malmgren 1961). The partners on both ends of a global pipeline have to develop a joint interpretative context in order to engage in interaction. Firms have to be able to understand different institutional regimes in order to communicate and interact with actors in other parts of the world through global pipelines (Owen-Smith and Powell 2002). This requires complex capabilities, which are not that easy to achieve as firms tap into particular cultures which can vary between places, regions and states. The case studies reviewed by Schoenberger (1999) and Dicken (2001) of multinational firms which have run into trouble when expanding their production networks to other countries exemplify this. Gertler (2001b) points out that systematic influences of institutions, especially between different national environments, prevent the diffusion of universal operational standards or a single 'best practice'. "The nation-state (whether 'home' or 'host') is still a primary source of influence over industrial practices" (Gertler 2001b: 16). In fact, it is quite possible that through a lack of understanding of different institutional contexts communication might be almost impossible. In this case, firms would continue 'speaking different languages'. It would be impossible to translate messages between these institutional contexts and to establish common interpretative schemes.

To successfully establish a global pipeline therefore requires the development of a shared institutional context which enables joint problem-solving, learning and knowledge creation. This involves intense efforts to develop joint action frames and projects. Through experience trust may gradually develop over time enabling more complex interaction (Harrison 1992). This process requires investments and resources, and the total number of pipelines a firm is able to handle is likely to increase with size. Still, it can be expected that there is limitations to the number of pipelines each firm can develop and handle. To avoid the risk of costly failure in establishing global pipelines, firms are likely to develop selection routines. A decisive question then is how to properly select potential partners for the establishment of global pipelines. We suggest that this can be accomplished through numerous mechanisms. A firm might for instance rely on reputation effects to make contact with extra-local actors (Lorenz 1999, Glückler and Armbrüster 2003). Alternatively, firms can also scan their environment through a mobilisation of 'weak ties' (Granovetter 1973) or use regular conventions and trade-fairs to establish contact with potential partners which they have known through former such events. In addition, firms establish branches or acquire other firms in 
distant clusters in order to develop local linkages within new locations and their respective markets. The new linkages may have the character of extra-local pipelines but they may also benefit from knowledge transfers between the buzz of different clusters.

Since the establishment of a pipeline is a conscious attempt to overcome identified shortcomings in the local knowledge base and fulfil certain goals and expectations, actors are also prepared to make special efforts to bridge cognitive distance. While interaction requires that actors at both ends of the pipeline have some mix of similar and non-similar knowledge (Nooteboom 2000, Nonaka, Toyama and Nagata 2000), we may assume that this particular mix of knowledge has a different structure than that enabling local buzz (Lawson and Lorenz 1999). It seems particularly important in the selection of external partners that the degree of overlap in capabilities and knowledge assets is not too great. The lower threshold to establish such a relation is most likely the existence of a minimum amount of non-similar knowledge. Only in this case will the necessary investments to create the new relation be justified.

\section{Absorptive capacity}

Identifying the value and location of external knowledge and building pipelines to access that knowledge is, however, only part of the challenge when attempting to boost a firm's innovative capability. An equally immense task is to establish the ability to assimilate the information arriving through pipelines and to apply it successfully towards commercial ends. A firm's ‘absorptive capacity' (Cohen and Levinthal 1990) depends not only on its direct interface with its local environment and on the number and extent of its pipelines, but also on the way whereby information can be transferred across and within departments and sub-units which may be removed from the point where the pipelines enter into the firm. The role of internal gatekeepers and boundaryspanners becomes crucial for translating externally produced knowledge into a form that can be internally understood by the departments or individuals for whom it is particularly valuable. In this sense absorptive capacity can be seen as a mediating variable between the firm's environment and its organisational adaptation. ${ }^{23}$ In the case

\footnotetext{
${ }^{23}$ See van den Bosch, Volberda and de Boer (1999). Aage (2001) appears to be the first who introduced the literature of absorptive capacity in the context of industrial districts while independently pursuing a similar line of investigation.
} 
of the Leipzig media industry cluster, actors and firms are clearly lacking this capability to systematically access external markets and establish pipelines with extra-local customers (Bathelt 2001). This lack of 'absorptive capacity', which is related to the ruptures in the political and economic system which were associated with the German Reunification, also limits the opportunities for local interaction and growth.

Firms build pipelines to access knowledge that is not already part of their repertoire. Yet if too different from the present mental representations, genuinely new knowledge may easily be ignored or treated as something unique and therefore not taken seriously enough (Durham 1991, 1992). The concept of absorptive capacity emphasises both the role of diversity of expertise and its distribution within the firm for creating new mental maps which integrate new knowledge arising outside the firm. Both aspects influence the aptness to cope with knowledge that cannot easily be broken down into separate pieces to be processed by a clearly defined organisational hierarchy. The distribution of expertise also affects how knowledge, which arrives through the pipelines and is dispatched by the local gatekeepers, will be understood and handled by the individuals who receive it in the various departments and sub-units of the firm. The background knowledge which is required by the group of employees as a whole when aiming at maximising the value of information consists of shared language and symbols. But if all individuals in the firm share precisely the same specialised language and symbolic representations they will not be able to tap into diverse external knowledge sources even if the relevant pipelines were in place.

\section{A buzz-and-pipeline model of cluster competitiveness: concluding discussion}

We can now sum our argument in terms of a number of points which form an embryonic knowledge- and learning-centred theory of clustering. This aims to explain why firms can gain competitive advantage by being co-located in a cluster with many other firms and organisations which are involved in similar and related types of economic activity.

Figure 1 exemplifies a cluster of interrelated actors and firms which are bound together through inter-firm transaction and communication linkages within a particular value chain. Within this cluster, information flows, gossip and news create a complex multi- 
layered information and communication ecology which we refer to as local buzz. This buzz encourages the development of shared values, attitudes and interpretative schemes, typical for communities of practice, which enable the local actors to engage in interactive learning and problem solving, and give meaning to complex information about changes in markets and technologies. Everyday communication patterns and routines also serve to create coherence within the cluster - through the "powers of association', in the language of actor-network theory (Latour 1986). Figure 1 also emphasises that a cluster can by no means be restricted to any discrete regional scale. Spaces of shared meaning and identity are established through ongoing interactions between actors and firms over time. The resulting values, norms and other institutional arrangements may easily include actors which are located outside the region. In addition, not all regional actors and firms are part of the cluster and share its particular values and interpretative schemes.

\section{[FIGURE 1 SOMEWHERE HERE]}

\section{Main propositions of the model}

The basic argument should be obvious: the existence of local buzz of high quality and relevance leads to a more dynamic cluster. In this case it is beneficial to be surrounded by other actors with relevant similar and non-similar skills and competencies. These actors and their buzz are, however, of little relevance if firms are not 'tuned in'. In order for the buzz to be valuable, it has to be comprehensible and include enough useful information. It is likely that a milieu, where many actors with related yet complementary and heterogeneous knowledge, skills and information reside, provides a great potential for dynamic interaction.

The second argument addresses the role of extra-local sources of knowledge, i.e. the pipeline structure. A well-developed system of pipelines connecting the local cluster to the rest of the world is beneficial for the cluster firms in two ways. First, each individual firm can benefit from establishing knowledge-enhancing relations to actors outside the local cluster. Even world-class clusters cannot be permanently self-sufficient in terms of state-of-the-art knowledge creation. New and valuable knowledge will always be created in other parts of the world and firms who can build pipelines to such sites of global excellence gain competitive advantage. Second, it seems reasonable to assume 
that the information that one cluster firm can acquire through its pipelines will spill over to other firms in the cluster through local buzz. Our hypothesis therefore is that the more developed the pipelines between the cluster and distant sites of knowledge, the higher the quality (and value) of local buzz benefiting all firms in the local cluster. This is why a firm will learn more if its neighbouring firms in the cluster are globally wellconnected rather than being more inward-looking and insular in their orientation.

The third argument highlights the intrinsic trade-off between a too much inward-looking and a too much outward-looking organisational structure. In the first case knowledge is easily transmitted throughout the firm, but new external knowledge sources can be difficult to comprehend. In the latter case the external information can be understood and translated by the gate-keepers, but the internal communication gaps may prevent it from reaching the units where it could be transformed into commercially useful knowledge. However, if the buzz is sufficiently intense some such derelict knowledge may come into productive usage anyhow through highly informal channels of communication using unconventional interpretative schemes. Some may even spill over and become unravelled and applied by other firms in the cluster without the initial receiver ever benefiting from the particular transfer. The investments needed in other settings for building an appropriate receiving capacity for deciphering and restructuring knowledge coming through the pipeline will thus, at least in part, be substituted by the free benefits of the buzz for firms located in clusters.

The fourth and final argument of the model is that there are limits to the number of pipelines that an individual firm can manage simultaneously. One could hypothesise that a large number of related independent firms in a cluster can manage a larger number of pipelines than one single large firm alone. If this is true, this could provide a possible explanation why spatial clustering gives rise to competitive advantage. This would also help to explain why a cluster of many firms is better that a one-company town in terms of long-term competitiveness.

\section{Countervailing forces and limitations}

One problem with the set of propositions made above is that they do not include any notion of an upper limit to the benefits of spatial clustering. The larger the number of similar and related firms in a spatial cluster, the more vibrant and valuable the local 
buzz; the more firms, the greater the potential for well-developed global pipelines; the more well-developed these pipelines, the more refined the buzz. Could we think of countervailing forces which limit the benefits of spatial clustering? In that case the above hypotheses would have to be modified in such a way that a balance between vibrant buzz and information overload or between global openness and internal coherence is possible.

One such countervailing force could be that of buzz congestion. Can a cluster become so over-crowded that there is too much buzz? Then it would be difficult for an individual actor to make sense of the buzz and identify important information. Can a firm - or rather the individuals within a firm - located in an extremely 'buzz-intensive' cluster begin to suffer from information overload or information fatigue-syndrome, as this situation has been termed? Information overload is believed to induce psychological, physical and social problems which show up in a lack of direction, absence of a common interpretative framework, paralysis of analytical capacity, on-going search for more information, increased anxiety and poor decision-making (Buchanan and Kock 2001). Goulding (2001) argues that those being exposed to information overload are at risk of suffering the same fate as the information-poor. The information-poor actors are unable to take action because they do not have that information necessary to enable them to act efficiently. The information-rich actors are also paralysed simply due to their inability to create order and attach meaning to the buzz around them. The paradox is that it is difficult to obtain useful, relevant information when needed, although there is an abundance of information.

Information overload is usually discussed in the context of developments in media and information and communication technologies or with problems facing managers in certain situations (Penrose 1959). Solutions put forward to reduce such overload often include the use of various types of filters to separate important and relevant information from irrelevant, unclear and inaccurate fragments of information (cf. Edmunds and Morris 2000). The selection is effected through discriminative attention processes (Witt 1999), based on the common cognitive frame developed over time among the firms in the cluster. Knowledge that has passed this cognitive filter is evaluated every time it is used by critical local actors. Unreliable or otherwise low-quality knowledge tends to be weeded out before it enters into general usage. Even though a vibrant cluster may be a 
stressful place in many ways, it can be argued that it also functions as an efficient information-filter and -management structure. In a cluster, information is constantly being evaluated, compared to existing knowledge and tested out. The advantage of local buzz is that each piece of information which is transmitted face-to-face has already been tested for relevance and customised to the receiver. Information overload would, thus, normally not be a major problem in the context of local buzz.

Another possible countervailing force revolves around the relation between welldeveloped pipelines and the quality of the local buzz. While external linkages can support regional growth processes, when they are too strong they could threaten the long-term existence of a cluster. Strong external linkages could then provoke segmentation among the members of a cluster, reducing its coherence and threatening its long-term future (Bathelt and Taylor 2002). The argument here is that when actors focus primarily on external linkages global pipelines begin to dominate the local milieu. Therefore, less attention is being paid to local communication and information flows and people are less interested to participate in local broadcasting. As a consequence, the local buzz becomes quieter and the reasons for firms to locate and remain in the cluster evaporate. Such 'hollow clusters' might not survive in the long-term as firms eventually shift to other locations. This risk is, however, partly kept at bay as there is likely an upper limit to the number of pipelines one individual firm can manage. In addition, the low costs and automatic nature of the local buzz serve as a self-preserving mechanism. Still, this danger is real. A cluster which is more or less empty because its important actors are constantly travelling the world in order to build and maintain an extensive pipeline system will run an obvious risk of becoming less vibrant.

\section{Policy implications}

Our final comments are directed towards the policy implications of the line of argument developed in this paper. Policy ambitions and initiatives to build, support and develop spatial clusters of similar and related economic activity have been abundant in recent years, in the OECD world and beyond. The majority of such efforts are directed towards encouraging and developing mechanisms that promote the potential for interactive learning and knowledge creation across firms and other organisations within a spatially defined cluster. The arguments put forward in this paper partly question such initiatives as being insufficient. Local networking is, of course, an important issue and needs to be 
addressed in local development policies. The local buzz is certainly dependent on particular local institutional preconditions but the important point is that it largely takes care of itself. If a number of actors are placed within a region some sort of buzz will automatically result (even in prisons, where the inmates are kept apart from one another in order to limit information spill-over, a lot of buzz occurs).

In contrast, it is especially the development of global pipelines which requires institutional and infrastructure support. Of course, we do not suggest that cluster firms should be exclusively outward-oriented as this would reduce internal cohesiveness within the cluster and ultimately threaten its existence. Still, recent cluster policies are so predisposed toward local networking that the importance of external, trans-local communication is overlooked. Perhaps it would be wiser for policy actors to consider the possibilities of stimulating pipeline development rather than to make extensive efforts in generating and promoting local buzz through various forms of social engineering.

\section{Acknowledgements}

Earlier versions of this paper were presented in September 2002 at the Second International Symposium on "Knowledge and Space" in Heidelberg and in March 2003 at the Annual Meeting of the Association of American Geographers in New Orleans. Thanks are due to Bjørn Asheim, Trevor Barnes, Jonathan Beaverstock, Jeff Boggs, Peter Meusburger, James Murphy, Steven Shapin, Eric Sheppard, Sally Weaver and other participants for their helpful comments. We would also like to thank Peter Dicken, Hubert Schmitz and the three anonymous referees for their insightful remarks and suggestions. The authors of this paper acknowledge the support provided by the DFG (German Research Foundation), the Bank of Sweden Tercentenary Foundation and Vinnova, and Centre for Economic and Business Research (CEBR) respectively. 


\section{References}

Aage, T. (2001) External relations and industrial districts. Paper presented at the DRUID Nelson and Winter Summer Conference (URL: http://www.druid.dk/conferences/nw/paper1/aage.pdf).

Allen, J. (1997): Economies of power and space. In: Lee, R. and Wills, J. (Eds.): Geographies of Economies. pp. 59-70. London: Arnold.

Almeida, P. and Kogut, B. (1999): Localization of knowledge and the mobility of engineers in regional networks. Management Science 45 (7): 905-917.

Amin, A. and Thrift, N. (1992): Neo-Marshallian nodes in global networks. International Journal of Urban and Regional Research 16: 571-587.

Asheim, B. (1999): Interactive learning and localised knowledge in globalising learning economies. GeoJournal 49: 345-352.

Bathelt, H. (2001): The Rise of a New Cultural Products Industry Cluster in Germany: the Case of the Leipzig Media Industry. IWSG Working Papers 06-2001 (URL: http://www.unifrankfurt.de/fb11/wigeo/index.html). Frankfurt/ Main.

Bathelt, H. (2002): The re-emergence of a media industry cluster in Leipzig. European Planning Studies 10: 583-611.

Bathelt, H. and Glückler, J. (2002): Wirtschaftsgeographie: Ökonomische Beziehungen in räumlicher Perspektive (Economic Geography: Economic Relations in Spatial Perspective). Stuttgart: UTB - Ulmer.

Bathelt, H. and Taylor, M. (2002): Clusters, power and place: inequality and local growth in time-space. Geografiska Annaler 84 B: 93-109.

Belussi, F. and Pilotti, L. (2002): Knowledge creation, learning and innovation in Italian industrial districts. Geografiska Annaler 84 B: 125-139.

Bresnahan, T., Gambardella, A. and Saxenian, A. (2001): 'Old economy' inputs for 'new economy' outcomes: cluster formation in the new Silicon Valleys. Industrial and Corporate Change 10: 835-860.

Brown, J. S. and Duguid, P. (1991): Organizational learning and communities of practice: toward a unified view of working, learning, and innovation. Organization Science 2: 40-57.

Buchanan, J. and Kock, N. (2001): Multiple criteria decision making in the new millennium. Lecture notes in Economics and Mathematical Systems 507: 49-58.

Burt, R. S. (1992): Structural Holes: The Social Structure of Competition. Cambridge (MA), London: Harvard University Press.

Camagni, R. (Ed.) (1991): Innovation Networks: Spatial Perspectives. London, New York: Belhaven Press.

Chandler, A. D. (1962): Strategies and Structure. Chapters in the History of the International Enterprise. Cambridge (MA): MIT Press.

Chapman, K. and Walker, D. (1987): Industrial Location: Principles and Policies. Oxford, New York: Basil Blackwell.

Cohen, W. M. and Levinthal, D. A. (1990): Absorptive capacity: a new perspective on learning and innovation. Administrative Science Quarterly 35: 128-152. 
Crevoisier, O. and Maillat, D. (1991): Milieu, industrial organization and territorial production system: towards a new theory of spatial development. In: Camagni, R. (Ed.): Innovation Networks: Spatial Perspectives. pp. 13-34. London, New York: Belhaven Press.

DeBresson, C., Xiaoping Hu, Drejer, I. and Lundvall, B.-A.. (1997): Innovative Activity in the Learning Economy - A Comparison of Systems in Some OECD Countries. Paper presented at the OECD Workshop on 'National Systems of Innovation and Catching Up' in Seoul.

Dicken, P. (2001): 'Placing’ firms - ‘firming’ places. Paper presented at the Meeting of German Geographers in Leipzig.

Durham, W. H. (1991): Co-evolution: Genes, Culture and Human Diversity. Stanford: Stanford University Press.

Durham, W. H. (1992): Applications of evolutionary cultural theory. Annual Review of Anthropology 19: 331-335.

Eccles, R. G. (1983): Transfer Pricing, Fairness and Control. Working Paper 167. Harvard Business School.

Edmunds, A. and Morris, A. (2000) The problem of information overload in business organisations: a review of the literature. International Journal of Information Management 20 (1): 17-28.

Erikson, R. (1974): The regional impact of growth firms: the case of Boeing 1963-1968. Land Economics 50: $127-136$.

Freeman, C. (1982): The Economics of Industrial Innovation. London: Pinter.

Freeman, C. (1991): Networks of innovators: a synthesis of research issues. Research Policy 20 (5): 5-24.

Fuchs, M. (2001): Von der 'lernenden Region' zur 'lernenden Organisation' (From the Learning Region to the Learning Organization). INEF Report 52/2001. Duisburg: INEF.

Fujita, M., Krugman, P. and Venables, A. J. (1999): The Spatial Economy. Cities, Regions and International Trade. Cambridge (MA): MIT Press.

Gertler, M. S. (1993): Implementing advanced manufacturing technologies in mature industrial regions: towards a social model of technology production. Regional Studies 27: 665-680.

Gertler, M. S. (1995): 'Being there': proximity, organization, and culture in the development and adoption of advanced manufacturing technologies. Economic Geography 71: 1-26.

Gertler, M. S. (2001a): Local Knowledge: Tacitness and the Geography of Context. Paper presented at the Annual Meeting of the Association of American Geographers in New York.

Gertler, M. S. (2001b): Best practice? Geography, learning and the institutional limits to strong convergence. Journal of Economic Geography 1: 5-26.

Gilmour, J. M. (1974): External economics of scale, interindustrial linkage and decisionmaking in manufacturing. In: Hamilton, F. E. I. (Ed.): Spatial Perspectives on Industrial Organization and Decision-making. pp. 335-362. London: Wiley.

Glückler, J. and Armbrüster, T. (2003): Bridging uncertainty in management consulting: the mechanisms of trust and networked reputation. Organization Studies 24: forthcoming.

Goodman, E., Bamford, J. and Saynor, P. (Eds.) (1989): Small Firms and Industrial Districts in Italy. London, New York: Routledge. 
Gordon, I. R. and McCann, P. (2000): Industrial clusters: complexes, agglomeration and/ or social networks. Urban Studies 37: 513-532.

Goulding, A. (2001) Information poverty or overload? Journal of Librarianship and Information Science 33 (3): 109-111.

Grabher, G. (1993): The weakness of strong ties: the lock-in of regional development in the Ruhr area. In: Grabher, G. (Ed.): The Embedded Firm. On the Socioeconomics of Industrial Networks. pp. 255277. London, New York: Routledge.

Grabher, G. (2001): Ecologies of creativity: the village, the group, and the heterarchic organisation of the British advertising industry. Environment and Planning A 33: 351-374.

Grabher, G. (2002a): Cool projects, boring institutions: temporary collaboration in social context. Regional Studies 36: 205-214.

Grabher, G. (2002b): The project ecology of advertising: tasks, talents and teams. Regional Studies 36: 245-262.

Granovetter, M. (1973): The strength of weak ties. American Journal of Sociology 78: 1360-1380.

Granovetter, M. (1985): Economic action and economic structure: the problem of embeddedness. American Journal of Sociology 91: 481-510.

Grotz, R. and Braun, B. (1993): Networks, milieux and individual firm strategies: empirical evidence of an innovative SME environment. Geografiska Annaler 75 B: 149-162.

Hagedoorn, J. and Schakenraad, J. (1992): Leading companies and networks of strategic alliances in information technologies. Research Policy 21: 163-181.

Håkansson, H. (1989): Corporate Technological Behaviour: Co-operation and Networks. London: Routledge.

Harrison, B. (1992): Industrial districts: old wine in new bottles? Regional Studies 26: 469-483.

Hoover, E. M. (1970): An Introduction to Regional Economics. New York: Knopf.

Humphrey, J. and Schmitz, H. (2002): How does insertion in global value chains affect upgrading in industrial clusters? Regional Studies 36: 1017-1027.

Karaska, G. J. (1969): Manufacturing linkages in the Philadelphia economy: some evidence of external agglomeration forces. Geographical Analysis 1: 354-369.

Kern, H. (1996): Vertrauensverlust und blindes Vertrauen: Integrationsprobleme im ökonomischen Handeln (Loss of trust and blind confidence in economic action). SOFI-Mitteilungen 24/1996: 7 14.

Kie, C. and Hynes, M. (1996): Where is the disintegration? Growth and Change (Winter 1996): 29-46.

Klepper, S. (2002): The Evolution of the U.S. Automobile Industry and Detroit as its Capital. Paper presented at the DRUID Winter Conference (URL: http://www.druid.dk/conferences/winter2002/gallery/klepper.pdf).

Kline, S. J. and Rosenberg, N. (1986): An overview of innovation. In: Landau, R. and Rosenberg, N. (Eds.): The Positive Sum Strategy: Harnessing Technology for Economic growth. pp. 275-306. Washington (D.C.): National Academy Press.

Kostiainen, J. (2002): Learning and the 'ba' in the development network of an urban region. European Planning Studies 10: 613-631. 
Krugman, P. (1991): Geography and Trade. Leuven: Leuven University Press \& Cambridge (MA), London: MIT Press.

Krugman, P. (2000): Where in the world is the 'new economic geography'? In: Clark, G. L., Feldman, M. P. and Gertler, M. S. (Eds.): The Oxford Handbook of Economic Geography. pp. 49-60. Oxford: Oxford University Press.

Latour, B. (1986): The powers of association. In: Law, J. (Ed.): Power, Action and Belief: A New Sociology of Knowledge? pp. 264-280. London: Routledge \& Kegan Paul.

Lawson, C. (1999): Towards a competence theory of the region. Cambridge Journal of Economics 23: 151-166.

Lawson, C. and Lorenz, E. (1999): Collective learning, tacit knowledge and regional innovative capacity. Regional Studies 33: 305-317.

Loasby, B. J. (2000): Organisations as Interpretative Systems. Paper presented at the DRUID Summer Conference (URL: http://www.druid.dk).

Loasby, B. J. (1999): Knowledge, Institutions and Evolution in Economic. Graz Schumpeter Lectures London: Routledge

Lorenz, E. (1999): Trust, contract and economic cooperation. Cambridge Journal of Economics 23: 301315.

Lundvall, B.-Å. (1988): Innovation as an interactive process: from user-producer interaction to the national system of innovation. In: Dosi, G., Freeman, C., Nelson, R. R., Silverberg, G. and Soete, L. L. G. (Eds.): Technical Change and Economic Theory. pp. 349-369. London: Pinter.

Lundvall, B.-Å. and Maskell, P. (2000): Nation states and economic development - From national systems of production to national systems of knowledge creation and learning. In: Clark, G. L., Feldman, M. P. and Gertler, M. S. (Eds.): The Oxford Handbook of Economic Geography. pp. 353-372. Oxford: Oxford University Press.

Maillat, D. (1998): Vom 'Industrial District' zum innovativen Milieu: Ein Beitrag zur Analyse der lokalen Produktionssysteme (From industrial networks to innovative milieus: towards an analysis of territorial production systems). Geographische Zeitschrift 86: 1-15.

Maillat, D., Léchot, G., Lecoq, B. and Pfister, M. (1997): Comparative analysis of the structural development of milieux: the watch industry in the Swiss and French Jura Arc. In: Ratti, R., Bramanti, A. and Gordon, R. (Eds.): The Dynamics of Innovative Regions: The GREMI Approach. pp. 109-137. Aldershot, Brookfield: Ashgate.

Malecki, E. J. (2000): Knowledge and regional competitiveness. Erdkunde 54: 334-351.

Malecki, E. J. and Oinas, P. (Eds.) (1999) Making Connections. Technological Learning and Regional Economic Change. Aldershot: Ashgate

Malmberg, A. and Maskell, P. (1997): Towards an explanation of industry agglomeration and regional specialization. European Planning Studies 5: 25-41.

Malmberg, A. and Maskell, P. (2002): The elusive concept of localization economies: towards a knowledge-based theory of spatial clustering. Environment and Planning A 34: 429-449.

Malmgren, H. B. (1961): Information, expectations and the theory of the firm. Quarterly Journal of Economics 75 (3): 399-421.

Markusen, A. (1996): Sticky places in slippery space: a typology of industrial districts. Economic Geography 72: 293-313. 
Marshall, A. (1920): Principles of Economics. 8th edition. Philadelphia: Porcupine Press.

Marshall, A. (1927): Industry and Trade. A Study of Industrial Technique and Business Organization; and Their Influences on the Conditions of Various Classes and Nations. 3rd edition. London: Macmillan.

Martin, R. and Sunley, P. (2001): Deconstructing Clusters: Chaotic Concept or Policy Panacea? Paper presented at the Regional Studies Conference on 'Regionalising the Knowledge Economy' in London.

Maskell, P. (2001a): Towards a knowledge-based theory of the geographical cluster. Industrial and Corporate Change 10: 921-94

Maskell, P. (2001b) Knowledge creation and diffusion in geographic clusters International Journal of Innovation Management 5 (2): 213-237

Maskell, P. and Lorenzen, M. (2003): 'The Cluster - and other current forms of Market Organization' DRUID Working Paper - available through <www.DRUID.dk>

Maskell, P. and Malmberg, A. (1999a): The competitiveness of firms and regions: 'ubiquitification' and the importance of localized learning. European Urban and Regional Studies 6: 9-25.

Maskell, P. and Malmberg, A. (1999b): Localised learning and industrial competitiveness. Cambridge Journal of Economics 23: 167-185.

Maskell, P., Eskelinen, H., Hannibalsson, I., Malmberg, A. and Vatne, E. (1998): Competitiveness, Localised Learning and Regional Development: Specialisation and Prosperity in Small Open Economies. London, New York: Routledge.

Møen, J. (2001): Is Mobility of Technical Personnel a Source of R\&D Spillovers? NEBR Report 7834.

Murdoch, J. (1995): Actor-networks and the evolution of economic forms: combining description and explanation in theories of regulation, flexible specialization, and networks. Environment and Planning A 27: 731-757.

Nonaka, I. and Takeuchi, H. (1995): The Knowledge-creating Company. New York: Oxford University Press.

Nonaka, I., Toyama, R. and Nagata, A. (2000): A firm as a knowledge-creating entity: a new perspective on the theory of the firm. Industrial and Corporate Change 9: 1-20.

Nooteboom, B. (2000): Learning and Innovation in Organizations and Economies. Oxford: Oxford University Press.

Oakey, R., Rothwell, R. and Cooper, S. (1988): The Management of Innovation in High-Technology Small Firms: Innovation and Regional Development in Britain and the United States. London: Pinter.

OECD (1992): Industrial Policy in the OECD Countries. Annual Review. Paris: The Organisation for Economic Co-Operation and Development.

Oinas, P. (1999): Activity-specificity in organizational learning: implications for analysing the role of proximity. GeoJournal 49: 363-372.

Owen-Smith, J. and Powell, W. W. (2002): Knowledge Networks in the Boston Biotechnology Community. Paper presented at the Conference on 'Science as an Institution and the Institutions of Science' in Siena. 
Pavitt, K. (1999): Division of labour in the innovating firm. In: Dow, S. C. and Earl, P. E. (Eds.): Contingency, Complexity and the Theory of the Firm. Essays in Honour of Brian J. Loasby, Volume II. pp. 138-155. Cheltenham: Elgar.

Penrose, E. (1959): The Theory of the Growth of the Firm Oxford: Oxford University Press

Perrin, J.-C. (1991): Technological innovation and territorial development: an approach in terms of networks and milieux. In: Camagni, R. (Ed.): Innovation Networks: Spatial Perspectives. pp. 3554. London, New York: Belhaven Press.

Porter, M. E. (1990): The Competitive Advantage of Nations. New York: Free Press.

Porter, M. E. (1998): Clusters and the new economics of competition. Harvard Business Review 76 (November-December):77-90.

Porter, M. E. (2000): Locations, clusters, and company strategy. In: Clark, G. L., Feldman, M. P. and Gertler, M. S. (Eds.): The Oxford Handbook of Economic Geography. pp. 253-274. Oxford: Oxford University Press.

Pred, A. (1976): The interurban transmission of growth in advanced economies: empirical findings versus regional-planning assumptions. Regional Studies 10: 151-171.

Pyke, F., Becattini, G. and Sengenberger, W. (Eds.) (1990): Industrial districts and inter-firm cooperation in Italy. Geneva: International Institute for Labour Studies.

Quévit, M. (1991): Innovative environments and local/international linkages in enterprise strategy: a framework for analysis. In: Camagni, R. (Ed.): Innovation Networks: Spatial Perspectives. pp. 55-70. London, New York: Belhaven Press.

Rantisi, N. (2002): The local innovation system as a source of 'variety': openness and adaptability in New York City’s Garment District. Regional Studies 36: 587-602.

Ratti, R., Bramanti, A. and Gordon, R. (Eds.) (1997): The Dynamics of Innovative Regions: The GREMI Approach. Aldershot, Brookfield: Ashgate.

Rosenberg, N. (1982): Inside the Black Box: Technology and Economics. Cambridge, New York: Cambridge University Press.

Rosenkopf, L. and Almeida, P. (2001): Overcoming Local Search Through Alliances and Mobility. The Warton School (Mimeo).

Saxenian, A. L. (1994): Regional Advantage. Culture and Competition in Silicon Valley and Route 128. Cambridge (MA), London: Harvard University Press.

Schickhoff, I. (1983): Materialverflechtungen von Industrieunternehmen. Eine empirische Untersuchung am Beispiel von Industrieunternehmen am linken Niederrhein (Material Linkages of Industrial Firms. An Empirical Investigation in the Lower Rhine Valley). Habilitationsschrift, Universität Gesamthochschule Duisburg. Duisburg.

Schoenberger, E. (1999): The firm in the region and the region in the firm. In: Barnes, T. J. and Gertler, M. S. (Eds.): The New Industrial Geography: Regions, Regulation and Institutions. pp. 205-224. London: Routledge.

Scott, A. J. (1988): New Industrial Spaces: Flexible Production Organization and Regional Development in North America and Western Europe. London: Pion.

Scott, A. J. (1998): Regions and the World Economy: The Coming Shape of Global Production, Competition, and Political Order. Oxford, New York: Oxford University Press. 
Scott, A. J. (2002): A new map of Hollywood: the production and distribution of American motion pictures. Regional Studies 36: 957-975.

Simon, H. A. (1985): What we know about the creative process. In: Kuhn, R. L. (Ed.): Frontiers in Creative and Innovative Management. pp. 3-20. Cambridge (MA): Ballinger.

Simon, H. A. (1991): Bounded rationality and organizational learning. Organization Science 2: 125-134.

Smith, A. (1776): An Inquiry into the Nature and Causes of the Wealth of Nations. London: Strahan and Cadell.

Staber, U. (1997): Specialization in a declining industrial district. Growth and Change 28: 475-495.

Storper, M. (1995): The resurgence of regional economics, ten years later. European Urban and Regional Studies 2: 191-221.

Storper, M. (1997): The Regional World. Territorial Development in a Global Economy. New York, London: Guilford.

Storper, M. and Venables, A. J. (2002): Buzz: The Economic Force of the City. Paper presented at the DRUID Summer Conference on 'Industrial Dynamics of the New and Old Economy -- Who is Embracing Whom?’ in Copenhagen \& Elsinore.

Teece, D. J. (1980): Economies of scope and the scope of the enterprise. Journal of Economic Behavior and Organization 3 (1): 223-247.

Tracey, P., Clark, G. L. and Lawton Smith, H. (2002): Cognition, Learning and European Regional Growth: An Agent-Centred Perspective on the 'New' Economy. Paper presented at the Annual Meeting of the Association of American Geographers in Los Angeles.

Uzzi, B. (1996): The sources and consequences of embeddedness for the economic performance of organizations: the network effect. American Sociological Review 61: 674-698.

Uzzi, B. (1997): Social structure and competition in interfirm networks: the paradox of embeddedness. Administrative Science Quarterly 42: 35-67.

van den Bosch, F. A. J., Volberda, H. W. and de Boer, M. (1999): Coevolution of firm absorptive capacity and knowledge environment: organizational forms and combinative capabilities. Organizational Science 10 (5): 551-568.

Vatne, E. (2001): Local versus Extra-local Relations: The Importance of Ties to Information and the Institutional and Territorial Structure of Technological Systems. Paper presented at the Annual Residential Conference of the IGU Commission on the Dynamics of Economic Spaces in Turin.

von Hayek, F.A. (1937): Economics and knowledge. Economica IV (New series) (13): 33-54.

von Hayek, F.A. (1945): The use of knowledge in society. American Economic Review 35 (4): 519-530.

Weber, A. (1909): Über den Standort der Industrien. Erster Teil: Reine Theorie des Standorts (On the Location of Industries. Part I: Pure Location Theory). Tübingen: Mohr (Siebeck).

Wenger, E. (1998): Communities of Practice: Learning, Meaning, and Identity. Cambridge: Cambridge University Press.

Witt, U. (1999) Do entrepreneurs need firms? A contribution to the missing chapter in Austrian economics. Review of Austrian Economics 11: 99-109

Young, A. (1928): Increasing returns and economic progress. Economic Journal 38: 527-542. 
Figure 1. The structure and dynamics of local buzz and global pipelines

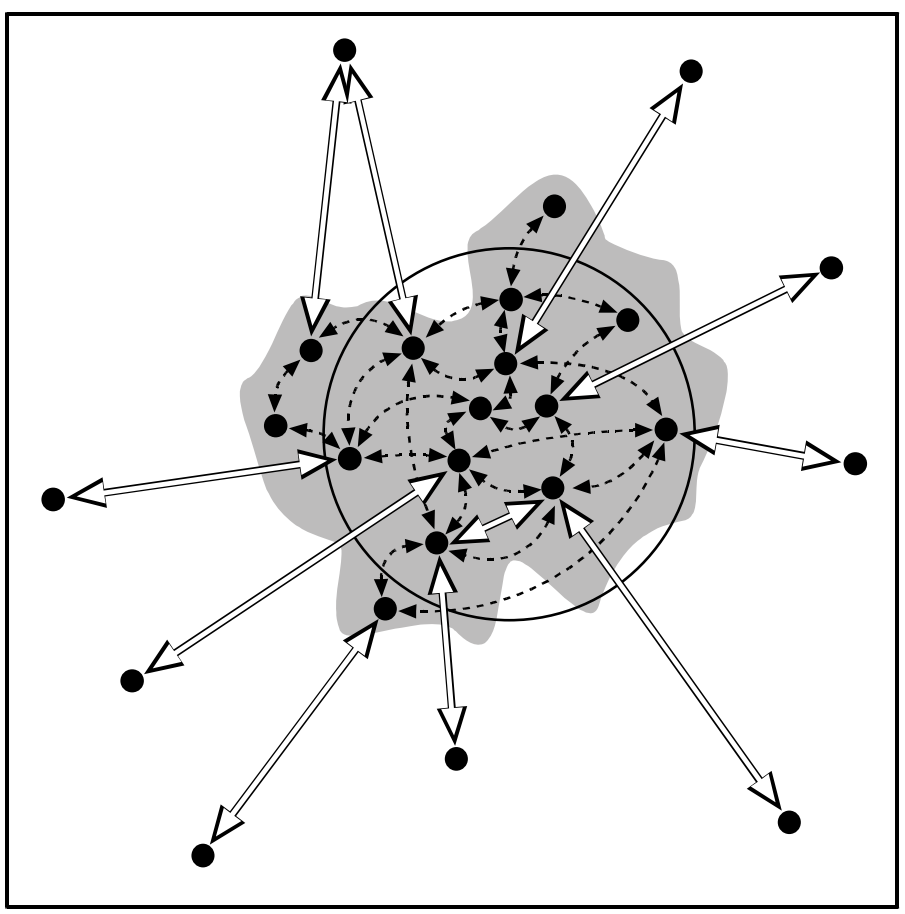

\title{
Local buzz and global pipelines
}

\author{
actors, firms \\ ( region \\ shared values, attitudes, \\ interpretative schemes \\ $\rightarrow$ local information flows \\ gossip, news, buzz \\ $\longleftrightarrow$ global pipelines
}

